\title{
The Importance of EconomicValue Added (EVA) and Studies Related To It in Kuwaiti Firms: A Critical Literature Review
}

\section{Hjar Mosaed AL Osaimi}

2 . Mobile : 0096597222224

3. Email : hajaralosaimi@gmail.com

: ireplyy@gmail.com

4 . Public Authority of Applied Education - Business Studies

\section{5 . Master Degree}

\begin{abstract}
This study aims two folds. First, it aims to investigate the importance of using economic value added(EVA ) in the evaluation of financial performance in the companies worldwide and how it is used. Second, it aims to reveal the fact about the extent to which studies abouteconomic value added(EVA) are conducted in Kuwait .To achieve this, the researcher has used Google search engine looking for any literature relevant to such subject matter. Many keywords were applied in Arabic and English language. Results revealed thatvarious scholars claimed that (EVA) is more essential in measuring the real financial performance of companies and that it is popular in many countries specially the developed ones to measure financial performance of the corporate sector. In addition, the study found that there are too many formulas or equations that may be used to calculate EVA. More importantly, the results showed that Kuwait, as well as most of the developing countries, has conducted lesser studies about EVA as well as having little concerns with regards to EVA's application as a tool for measuring the performance of the financial companies
\end{abstract}

Keywords: Kuwait, Economic value added (EVA), Profit, Earnings, Performance measures 


\section{Introduction}

The effectiveness of corporate management and the efficiency of employing resource affects directly the economic development of the country by yielding a positive financial performance. Therefore, analyzing the financial performance of companies is particularly important an crucial for managementto maintain the stability of the company and increase its market share.. However, there are many indicators that measure such financial performance.In general, financial performance was measuredvia its ability to make profits. Therefore, firms are usedto rely on classic financial indicators to evaluate their performance. The classical indicators include ROA, ROE, ROI. etc.). However, It has recently been shown that global status of the economic entity at a specific time is based on nonclassical indicators. Non-classical indicators are related to the concept of value creation and therefore it is more appropriate than classical indicators as they are based on the value added to a firm.

However, according to literature, most firms in Kuwait seem not be concerned about measuring financial performance using the economic value added (EVA) which is widely used in the developed countries. Therefore, this study is focused in reviewing the Economic Value Added (EVA) which is a non-classical indicator to measure the financial performance. Hence, given its importance, as we will see later, this study will attempt to review literature in terms of Eva's definition, equations, as well as its application by companies around the world. In addition to this, this study will investigate how developed countries are using extensively economic value added (EVA ) and the extent to which Kuwait is using it

\section{Financial performance}

The concept of financial performance has changed over time with completely different meanings. Stern Stewart consulting company introduced two performance indicators which are: market value added (MVA) and economic value added (EVA). TSR (Total Shareholder Return) and rate of return on cash flow - CFROI (Cash Flow Return on Investment) were proposed by Boston Consulting Group and HOLT Value Associates in Chicago promoted as efficiency indicators. Moreover, as a means of measuring performance, economic margins - EM (eng. Economic Margin) was proposed by Applied Finance Group. Moreover, the market value ratio (MBR), profit per share (EPS), price / income (PER, dividend yield are among other non-classical financial ratios used for the evaluation of companies' financial performances.

The new conceptsare mostly based on the fact that the company can only reaches its global performance by only meeting the interests of all stakeholders: managers, company owners, current and potential shareholders, business partners, creditors, employees and finally the state. To explain this, Managers seek to increase the market value of the; shareholders seek the ability to distribute their profits; credit institutions seek being repaid on time; employees seek fixed jobs and other benefits and finally the state seeks taxes being paid. However, obtaining the maximum profit is one of the main goals of any firm. Another goal is to increase the value of the company while taking into account the prosperity for owners. Such value measures the efficient implementation of the financial functions. Actually, to increasing this value, performance must be enhanced. To measure or evaluate financial performance, the analysis of financial statements is used to help in the prediction of the future conditions. Such analysis would anticipate whether a firm is going backward or forward. A drawbacks of this analysis is that it predicts the past, as it only show how the capital was used. This 
is due to the fact that such financial assessment mainly depended on the analysis of financial ratio which has its faults as it can't anticipate the future performance that which makes it unreliable. This expected unreliability of financial performance has led to look fornew approaches. One of these approaches is what is well known by EVA (economic value added). As a matter if fact, most scholars see this type of measurement as a more efficient method of measuring the performance of most firms where it is often referred as economic profit. For them, it one of the best ways to have a good picture at the real economic profit of any firm(Ende, 2017).

\section{Financial performance and economic value added (EVA)}

Every real asset and every financial asset has a value. When organizations have become more focused on creating value in the past decade, they tried to discover new mechanisms in order to measure this value.EVA is used to measure the surplus value that the company creates in its existing environment (Geyser and Liebenberg, 2003). In fact, it has become widely used in the West in assessing the performance of companies, unlike the third world countries, especially Kuwait, the Gulf and most of third World countries as well. Indeed, there are many ways to measure the corporate financial performance such as Accounting based performance measurements, Market based financial performance measurement, and Hybrid financial measurements. Indeed, economic value added (EVA) is an example of Hybrid financial measurements which is a complex combination of both accounting and market based measurements, (Castek and Pokorna 2013). Anyway, based on literature Table 1 shows the most common equations recently used to calculateEVA

Table 1: EVA equations

\begin{tabular}{|c|c|}
\hline & equations \\
\hline & $\begin{array}{l}\text { EVA }=(\text { Return on Capital- Cost of Capital }) \\
* \text { Capital }\end{array}$ \\
\hline & $\begin{array}{l}=(\text { Capital } * \text { Return on Capital })-(\text { Capital } * \\
\text { Cost of Capital })\end{array}$ \\
\hline & $=\left(\right.$ NOPAT_$\_(C a p i t a l * \text { Cost of Capital) }$ \\
\hline Economic Value Added & $=$ NOPAT - Capital Charge \\
\hline & or \\
\hline & $\begin{array}{l}\text { NOPAT - (Total Assets - Current Liabilities) * } \\
\text { WAC }\end{array}$ \\
\hline & NOPAT: Net Operating Profit After Taxes \\
\hline & $\begin{array}{l}\text { WACC: Weighted Average Cost of Capital } \\
\text { (WACC) }\end{array}$ \\
\hline
\end{tabular}

\section{Literature review}

\section{Definition of EVA}

There are many ways to measure the corporate financial performance such as Accounting based performance measurements, Market based financial performance measurement, and Hybrid financial measurements. Hybrid financial measurements are a complex combination of both accounting and market based measurements, an example on it is the economic value added (EVA) (Castek and Pokorna 2013). 
Stewart (1990) defined EVA as a financial performance measure as well as a tool. It is measure that is based on the value, and a tool that is used to make an investment decision. In addition, it is a performance measure that reflects the absolute amount of the created value for shareholders.

On the other hand, Pinto (2001) called EVA as economic profit (EP) for the purpose of avoiding the problems that the trademarking cause. Further, all concepts of the residual income are often called EVA too.

However, Vasilescu (2011) claimed that EVA is more powerful indicator in terms of estimating the business value. Not only this but he considered EVA as an understandable indicator for nonfinancial managers. In addition,ir was claimed that it refer to a long-term business evolution. EVA from Stern Value Management (2016) perspective is the best performance toolfor the shareholder value creation.

\section{Conceptual underpinnings for economic value added (EVA)}

Worthington, Andrew and West, Tracey (2001) provided a synoptic survey of the conceptual underpinnings for economic value added (EVA) and the comparatively few empirical analyses for it as well. The researchers paid special attention to the GAAP accounting adjustments in EVA-type measurement. The researchers reported that EVA is used to measure the internal, as well as the external financial performance, where EVA's conceptual underpinnings had been derived from the linkage between earnings and wealth creation (Bell, 1998). Furthermore, the researchers reported that EVA's thereby has close similarities with two other measures' sets. The first set contains the "Stern Stewart measure of Market Value-Added" (MVA). The second set contains "earnings before extraordinary items" (EBEI), net cash flow from operations (NCF) and finally residual income (RI).

\section{Scholars' suggested reviews Methodologies}

A study conducted by Anil K. Sharma and Satish Kumar (2010) revealed that there are Different methodologies to review literature related to Economic Value Added (EVA) that were used by the various scholars. Theyclassified them into four categories : conceptual, which cover basic concepts; descriptive, which provide description for EVA content; empirical and exploratory cross-sectional studies, which cover studies based on the analysis from databases and case studies. Om addotion, literaturerelated to EVA can be classified into seven sub- themes. These are "EVA and stock returns, EVAMVA relationship, managerial behavior and performance management, concept, criticism \& implementations issues of EVA, value management \& EVA, discounting approaches and their relationship with EVA and review studies on EVA"(Anil and Satish , 2010: P202)

\section{Equations of EVA}

According to Stewart (1991), EVA is calculated as:

$$
\text { Eq.(1) ............ EVA }=\left(\mathrm{r}-\mathrm{c}^{*}\right) \mathrm{X} \text { capital ............ }(\mathrm{r} \text { X capital })-\left(\mathrm{c}^{*} \mathrm{X} \text { capital }\right)
$$

Where: $r=$ the economic book value of the capital committed to the business multiplied by the spread between the rate of return on capital; $\mathrm{c}^{*}=$ the cost of capital

or

Eq.(2)..........EVA $=$ (rate of return - the cost of capital) $X$ capital 
where: $\mathrm{r}=$ the rate of return; $\mathrm{c}^{*}=$ the cost of capital, or more correctly stated, the WACC.

Eq.(3).......r $=\frac{\text { NOPAT }}{\text { capital }}$

...... NOPAT $=$ r X capital

Replacing ( $\mathrm{r}$ X capital) with NOPAT in Eq.(1): EVA becomes as follows:

\section{EVA $=$ NOPAT $-\left(c^{*} \mathbf{X}\right.$ capital $)$}

Where : NOPAT: operating profits; ( $c^{*} X$ capital): the capital charge.

On the other hand, Stern Value Management (2016) showed that EVA is an economic profit measurement, where it is calculated as:

The Net Operating Profit After Tax (NOPAT) _ the opportunity cost of invested Capital.

This opportunity cost is determined by: (Weighted Average Cost of debt) * (equity Capital $(\mathrm{WACC}))^{*}$ (the amount of Capital employed).

EVA equation becomes as follows:

\section{EVA = NOPAT - WACC * Capital.}

Furthermore, Stewart (1990) showed thatEVA is calculated as the excess return that is made on an investment and the capital invested in that investment. Moreover, EVA= (net operating profit) _ (the appropriate charge for the opportunity cost of all capital invested in the firm or in the project).

\section{The application of EVA by companies around the world}

EVA reflects the capital cost which is one of the most significant aspects. In addition, it corrects the problem of appearing the unjustified profitability, where it recognizes that when managers use the capital, they must pay for it. Moreover, by taking into consideration the equity cost, EVA shows the profit made or not made in each reporting period (Vasilescu and Popa, 2011).

EVA concept has gained an important attention in the developed economies (Sharma and Kumar, 2010) . However, Kuwait, Arabian Gulf countries as well as most of the developing countries show little concerns with regards to EVA's application as a tool for measuring the performance of the financial companies. This is very apparent in the few studies concerning EVA in Kuwait

In terms of EVA's application in the developed countries, Worthington and West (2004) aimed at their study to investigate whether EVA is highly related to stock returns in comparison with traditional common accounting-based measures. The researchers covered the period (1992 to 1998) and investigated 110 Australian companies. They described the linkages that exist between competing measures of the firm performance;

(ERN): earnings before extraordinary items, $(\mathrm{NCF})$ : net cash flow from operations, $(\mathrm{RI})$ : residual income, and (EVA): economic value-added.

Eq.(1) $\ldots \ldots \ldots . . . \mathrm{ERNt}=\mathrm{NCFt}+\mathrm{ACCt}$ 
Eq.(2) $\ldots \ldots \ldots \ldots . . . P R F t=E R N t+A T I t=N C F t+A C C t+A T I t$

Where :

PRFt: Net operating profit after tax

ATIt : after-tax interest expense

ACC : total accruals related to operating activities, it is composed of: depreciation, amortisation, changes in non-cash current assets, changes in current liabilities, and changes in the non-current portion of deferred taxes.

Eq. (3) $\ldots$... RIt $=\mathrm{PRFt}-(\mathrm{WACCt} \times \mathrm{CAPt}-1)=\mathrm{NCFt}+\mathrm{ACCt}+\mathrm{ATIt}-\mathrm{CCt}$ (capital Charge)

Where:

WACCt: the estimate of the firm's weighted average cost of capital

CAPt : assets (net of depreciation) invested in going-concern operating activities

CCt: capital Charge

Eq.(4) $\ldots \ldots \ldots \ldots . . . E V A t=\mathrm{NCFt}+\mathrm{ACCt}+\mathrm{ATIt}-\mathrm{CCt}+\mathrm{ADJt}$

Where:

ADJt: accounting adjustment

The results revealed that stock returns are related to EVA than residual income, earnings, as well as net cash flow, respectively.

On the other hand, the performance measures that explain and predict the performance of the company were examined by Parvaei and Farhadi (2013). The researchers examined for this matter 80 Iranian companies that are listed in Tehran stock exchange, where the researchers covered the period (2005 to 2009). Moreover, the study found that the best measurement that uses to evaluate the company's performance among other measures is EVA. Economic value added (EVA) was calculated by them as follows:

Eq. (1) ...........EVA = Adj NOPAT $-($ Capital Employed $\times$ WACC $)$

Where:

NOPAT $=$ Net operating profit after taxes

WACC $=$ weighted average cost of capital

Eq. (2) .......... Adj NOPAT $=$ Operating Profit $\times(1-$ Tax Rate $)+$ Provisions

Where:

Provisions $=$ Advertising Expense + R\&D Expense + Bad debt

Eq. (3) ...........WACC $=$ weke + wdkd $(1-$ Tax $)$ 
Where:

wd , we = debt' weight and common stock' weight, respectively

$k d, k e=$ Cost of debt and cost of equity, respectively

Eq. (4) $\ldots \ldots \ldots \ldots . . .=\mathrm{Krf}+\beta(\mathrm{Km}-\mathrm{Krf})$

Where:

$\mathrm{KRF}=$ Treasury Bills Rate of Return of Central Bank of Iran

$\mathrm{KM}=$ Market Index Rate of Return of Tehran Stock Exchange

$\beta=$ market risk for the stock of each firm

Eq. (4) .......... $\beta c=(\operatorname{Cov}(R m, R c)) /(\operatorname{var}(R c))$

Where:

$\mathrm{Rm}=$ periodic return of index

$\mathrm{Rc}=$ periodic stock return of firm $\mathrm{c}$

Eq. (6) .......... FCFF $=$ EBIT $(1-T)+$ Depreciation - Capital expenditures - Increase in NWC

Where:

$\mathrm{FCFF}=$ free cash flow for the firm

$\mathrm{EBIT}=$ earnings before interest and taxes

$\mathrm{NWC}=$ net working capital

Eq. (7) .......... RI $=$ NOPATt $-($ Capital Employedt $-1 \times \mathrm{WACCt})$

Where: RI: Residual income

Miron and Focsan (2017) aimed at their study to prove that the classical analysis method based on EVA is a perfectible method. The researchers used the theoretical approach and an empirical approach which dealt with a company from the Romanian energy sector. Moreover, the researchers conducted an empirical study by means of using data supplied by OMV Petrom SA, where the analysis range covered the period (2011-2015). After conducting some equations, the findings showed that EVA is perfectible, as well as adaptable to stakeholders' different informational needs.

The equations that the researchers used were as follows:

Eq. (1) .........EVA = PNE $-\mathrm{CKI}$

Where: PNE : net operating profit; CKI : invested capital. 
Eq. (2) $\ldots \ldots \ldots \ldots . \mathrm{PN}=\frac{P N}{C P R} * \frac{\mathrm{CPR}}{C P R+D} *(C P R+D)$

Where: PN: net profit; CPR: shareholders' equity; D: total liabilities.

Eq. (3) ........... CKI $=\mathrm{CI} * \mathrm{CMPC}$

Where: CMPC: weighted average cost of the capital, weighted average between the average interest rate and dividend distribution rate.

Replacing Eq.(2) and Eq. (3), in the original EVA's Eq.(1)

Eq.(4) ........ EVA $=\mathrm{PNCPR} * \mathrm{CPRCI} * \mathrm{CI}-\mathrm{CI} * \mathrm{CMPC}$

Removing the common factor CI from Eq. (4)

Eq. (5) ........EVA $=$ CI $($ PNCPR $*$ CPRCI - CMPC $)$

EVA equation becomes as follows:

EVA $=$ CI $($ PNCPR $*$ CPRCI - CMPC $)$ 


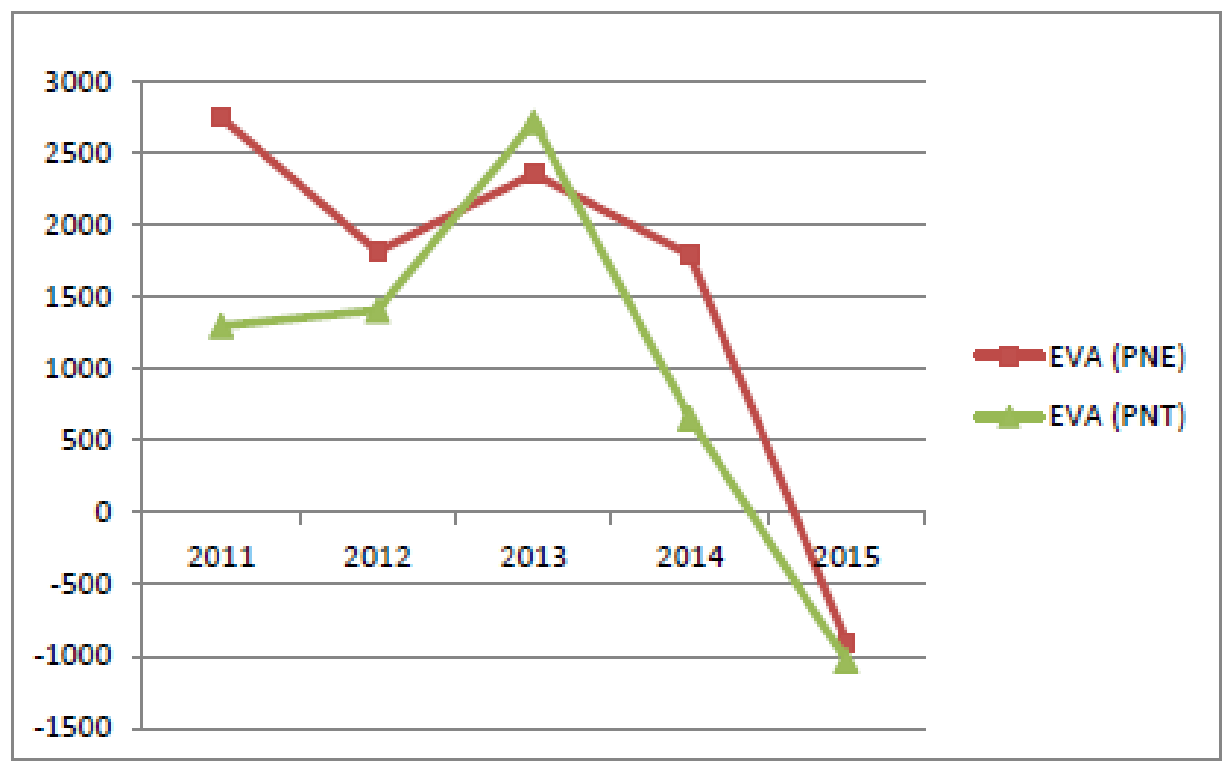

Figure 1 : Miron and Focsan (2017) calculating EVA based on the operating net profit \& total net profit

6. Eva in Kuwait 
However, though some studies claim thatKuwaiti firms use EVA as a tool in measuring financial performance, there found only studies that are fully focused in usingEVA as a tool in measuring financial performance in Kuwait. One of these study was conducted by Medhat (2013). It was focused on the explanatory power of the EVA and the traditional indicators for evaluating the performance of changes in the market value of shares by applying to the industry sector in the State of Kuwait (Nofal, 2013).

Nevertheless, Kuwait Direct Investment Promotion Authority is one of the most powerful economic arms of Kuwait. It was established in2013. The Offset Program seeks to achieve many primary goals. In addition to the primary goals it seeks to achieve economic value added benefits to Kuwait (K.D.I.P.A, 2014).

Abu-Aisheh and Alia Ali (2018)indicated that in order to encourage young people to be innovative and turn their ideas into economic value added (EVA) ideas, public and private institutional joint efforts shall be endeavored on providing a ground business foundation for entrepreneurs, providing financial grants, reducing legal and business obstacles, and fostering education, innovation and creativity. Indeed, Bani, et al., (2014)has went further in using Economic value added (EVA) model for measuring intellectual capital..

By looking to the tangibles and intangibles, sustainability contributes to shareholder value in three main pathways. The first pathway is that sustainable business practices can contribute in a direct way to tangible financial value by means of cost reduction, enabling growth, capital conservation, in addition, by means of risk reduction. The second pathway is that sustainability can improve in a direct way intangible assets, for instance; strategic relationships, reputation, brand equity, as well as innovation and human capital The third pathway is that sustainability can provide strategic advantage by means of creating for stakeholders a value. These pathways are shown in Figure 2 below. There is an important thing that should be noted to it; there are two tangible drivers that affect the shareholder value: asset utilization and profitability. This is harmonious with current financial metrics, for instance; Economic Value Added (EVA) or Return on Net Assets (RONA) (Joseph, et al., 2004).

Figure 2. Overview of pathways linking sustainability to shareholder value

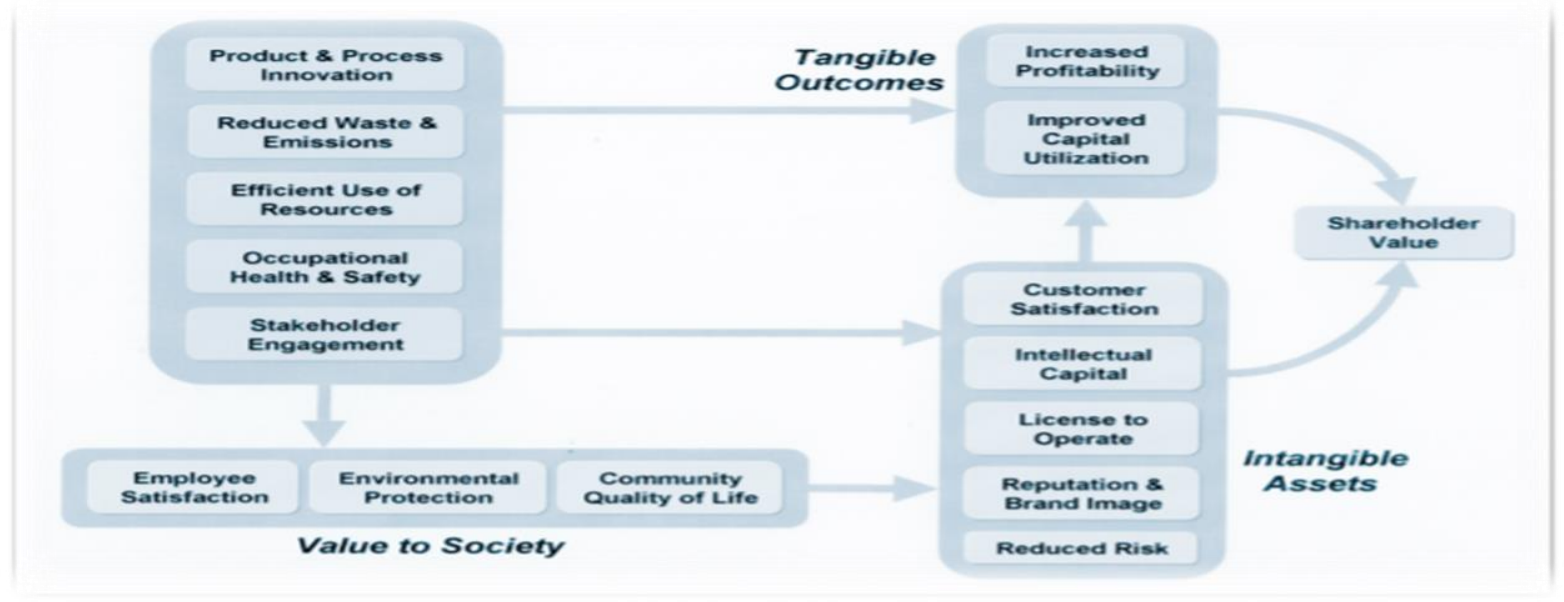


Sharma (2010) aimed at his study to present the literature review of 112 papers published on the EVA from the period of (1994 - 2008). The researcher found that EVA ( as a tool used to measure the firm's performance ) is supported significantly by developed countries and there are certain studies about it, whereas it is less supported by developing countries and there are a few number of studies about it. To take a good picture of that table 2 display the fact of country-wise publication of studies on EVA where Kuwait with Malaysia, Canada, Brazil, Greece, Russia, New Zealand, Turkey and Indonesia etc, have only two studies concerned about EVA.

Table 2. country-wise publication of studies on EVA

\begin{tabular}{|c|c|c|}
\hline S.no & Country & $\begin{array}{c}\text { No of Studies } \\
\text { Conducted }\end{array}$ \\
\hline 1 & USA & 51 \\
\hline 2 & India & 21 \\
\hline 3 & South Africa & 08 \\
\hline 4 & Australia & 05 \\
\hline 5 & UK 02 & 02 \\
\hline 6 & China & 02 \\
\hline 7 & ${ }^{*}$ Other & 2 \\
\hline $\begin{array}{l}* \\
\text { coversKuwait,Malaysia, Brazil, , Canada,Greece, New Zealand, Russia, Turkey } \\
\text { and Indonesia etc. adopted from (Anil and Satish, 2010) }\end{array}$ \\
\hline \multicolumn{2}{|l}{} \\
\hline
\end{tabular}

The effect of cash holdings and economic factors on EVA in the commercial banks in Jordan has been examined by Al-Nimri and Samerrai (2015). The researchers found that cash holdings, Net Interest Margin, Real Gross Domestic Product and inflation impact the EVA significantly from the statistical side. Furthermore, cash holdings value and the Real Gross Domestic product impact the EVA significantly from the statistical side under the shallow of the size of the bank. In addition, Net Interest Margin and inflation have no statistical impact on the EVA under the shallow of the size of the bank in Jordanian commercial banks.

Moreover, Emad Yousef (2012), aimed at his research to measure the relationship between traditional accounting measures of performance, return on assets (ROA), return on equity (ROE), EPS (Earning Per Share) and their effect on market value of stock prices. In addition, the research aimed at to measure the relationship between EVA's measurement and its effect on market value of stock prices. The appropriate statistical methods were used for the aim of testing the hypotheses on which the research was based. The findings of the research were as follows: there is a relationship between the traditional performance measures and the stock's market price in varying degrees. Furthermore, there is a relationship between EVA's measurement and the stock's market price, where the effect of EVA's measurement is greater than the effect of the traditional performance measures, moreover, the stock's market price is more related to EVA's measurement than traditional performance measures.

Mostly, the agricultural sector's value added in Kuwait is perceived and valued, unlike other parts of the world such as the USA, the European Union, as well as South America. The agricultural sector in these parts of the world has a strategic economic value added to these economies and a primary contributor to their Gross domestic productions (Faten, et al, 2014). 
Furthermore, Gharaibeh and Sarea (2015)aimed at their study " The Impact of Capital Structure and Certain Firm Specific Variables on the Value of the Firm: Empirical Evidence from KUWAIT" to study the effect of leverage and certain firm-characteristics on firm's value and on the decision to use debt, empirically. The researchers used 48 companies listed in the Kuwait Stock Exchange, where these companies represent four different sectors. The study found that the leverage impacts the firm's value significantly, where it was the most influential factor. In addition, the study found that when ROA is used as a proxy for the firm's value, the firm's value is affected significantly by size, business risk, growth opportunities, the value of the former year, dividends payout ratio, as well as liquidity. On the other hand, when ROE is used as a proxy of the firm's value, the firm's value is affected significantly by leveraging, growth opportunities , size, as well as liquidity.

On the other hand, Al-Matari (2011)examined in his study which entitled" Board characteristics and firm performance among Kuwaiti companies" to study the relationship between board characteristics and firm performance of non-financial Kuwaiti firms that are listed on the Kuwaiti stock exchange. Al-Matari found through this study that there is a significant positive relationship between CEO duality and ROA, a significant negative relationship between CEO tenure and ROA, a significant positive relationship between audit committee size with ROA, a significant negative relationship between board size and board composition, a positively insignificant relationship between firm size and ROA, as well as a negatively significant relationship between leverage and ROA.

\section{Discussion and Conclusions}

From the previous literature, this study found that

1. EVA has a vital role in corporate world.

2. EVA measure the real profit of the company

3. various scholars claimed that (EVA) is more essentialin measuring the real financial performance of companies

4. it is popularin many countries

5. EVA is more useful inmanufacturing industry. EVA is abetter for measuring real profitability it depends upon the valuecreation of shareholders.

6. EVA and Financial performance of the company is correlated.

7. It is an internal measure of performance used to quantify theshareholder value

8. used to manage the economic resources.

9. Many companies in 18 countries like; US, UK, South Africa,India,Australia, China, Malaysia, Canada, Brazil, Greece, Russia, New Zealand,Kuwait, Turkey and Indonesia, Kazakhstan, Saudi Arabia, Pakistan, Iran etc.have used EVA metric to measure financial performance of the corporatesector.

10. EVA is more useful for the developing country like; India to measureperformance of the company

11. EVA is more highly associated with stock returns and firm values than actual earnings.

12. There are too many formulas or equations that may be used to calculate EVA

13. Evidences of the superiority of EVA over classical tools are fluctuating between supportive and non-supportive 
14. Kuwait, as well as most of the developing countries have conducted lesser studies about EVA as well as little concerns with regards to EVA's application as a tool for measuring the performance of the financial companies

\section{References}

1. Abu-Aisheh, Alia Ali (2018). Entrepreneurship and Economic Growth: Case of Kuwait. "Applied Macroeconomic Theory" This paper has received the Kuwait Program at Sciences Po Student Paper Award. Sciences Po Kuwait Program

2. AL-MATARI, EBRAHIM MOHAMEED AYEDH (2011). BOARD CHARACTERISTICS AND FIRM PERFORMANCE AMONG KUWAITI COMPANIES. MASTER OF SCIENCE (INTERNATIOAL ACCOUNTING) UNIVERSITI UTARA MALAYSIA JUNE 2011

3. Al-Nimri , Ade Sameer, Samerrai, Kahtan (2015). The Impact of Cash Holdings and Economic Factors on the Economic Value Added in the Commercial Banks . Dirasat, Administrative Sciences, Volume 42, No. 1, 2015 - 329 - (C) 2015 DAR Publishers/University of Jordan. *

4. Anil K. Sharma and Satish Kumar (2010).Economic Value Added (EVA) - Literature Review and Relevant Issues. International Journal of Economics and Finance Vol. 2, No. 2; May 2010

5. Bani, Mahmoud, Homa Mehrpouyan and Maliheh Keshavarziyan. STUDY OF THE EFFECT OF INTELLECTUAL CAPITAL COMPONENTS AND FIRM SIZE. Kuwait Chapter of Arabian Journal of Business and Management Review Vol. 3, No.11; July. 2014212

6. Bell, L.W.W., 1998, Economic Profit: An Old Concept Gains New Significance, Journal of Business Strategy, 19, 5: 13-15.

7. Castek O., Pokorna J. (2013) How to measure organizational performance in search for factors of competitiveness. Acta universitatis agriculturae et silviculturae mendelianae brunensis. Vol. 56, No 2, pp 451-461.

8. Castek O., Pokorna J. (2013) How to measure organizational performance in search for factors of competitiveness. Acta universitatis agriculturae et silviculturae mendelianae brunensis. Vol. 56, No 2, pp 451-461.

9. Emad Youssef El Sheikh (2012). "A comparative study of the impact of the use of traditional performance measures and measures of economic value added on stock prices". Arab Journal of Administrative Sciences. (Arabic study).Volume: 19 Number: 2 2012.

10. Ende (2017). Financial Performance Analysis Using Economic Value Added(EVA)IOP Conf. Ser.: Mater. Sci. Eng. 180012250

11. Faten Jabsheh, Weam Behbehani, Noura Abdulmalek(2014). Agricultural Subsidies in the GCC: Between Cost and Benefit. The Case of Kuwait. Journal of Business and Economics, ISSN 2155-7950, USA April 2014, Volume 5, No. 4, pp. 573-595 DOI: 10.15341/jbe(2155-7950)/04.05.2014/012 $\square$ Academic Star Publishing Company, 2014 http://www.academicstar.us 573 
12. Geyser \& Liebenberg (2003). Creating a new valuation tool for south african agricultural co-operatives. Agrekon, vol 42, no 2 (june 2003).

13. Gharaibeh, Ahmad Mohammad Obeid, and Sarea, Adel Mohammed (2015). The Impact of Capital Structure and Certain Firm Specific Variables on the Value of the Firm: Empirical Evidence from KUWAIT. Corporate Ownership \& Control. Volume 13, Issue 1, 2015, pp. 1-10

14. Joseph Fiksel, Jonathan Low, Jim Thomas, Linking sustainability to shareholder value, June 2004 feature EM

15. Kuwait Direct Investment Promotion Authority, 2014

16. Nofal, Medhat Abdel-Rashid. Journal of Egyptian Accounting - Faculty of Commerce Cairo University - 2013 - Number 6

17. Miron and focsan (2017). The analysis of the performance of companies based on the economic value added. Annals of the „constantin brâncuşi” university of târgu jiu, economy series, issue $1 / 2017$

18. Parvaei, A., \& Farhadi, S. (2013). The Ability of Explaining and Predicting of Economic Value Added (EVA) versus Net Income (NI), Residual Income (RI) \& Free Cash Flow (FCF) in Tehran Stock Exchange (TSE). International Journal of Economics and Finance, 5(2), 67-77. http://dx.doi.org/10.5539/ijef.v5n2p67

19. PINTO F (2001). Economic value added. http//:www.evanomics.com (access 2002/06/03).

20. Ralph Palliam, (2006) "Further evidence on the information content of economic value added", Review of Accounting and Finance, Vol. 5 Issue: 3, pp.204-215, https://doi.org/10.1108/14757700610686417

21. Sharma, A. K. \& Kumar, S., 2010. Economic Value Added (EVA) - Literature Review. International Journal of Economics and Finance, 2(2), pp. 200-221.

22. Stern Value Management, 2016. Proprietary Tools. [Online] Available at: http://sternvaluemanagement.com/intellectual-property-joel-stern/proprietary-tools-valuecreation/ [Accessed 1611 2018].

23. Stern Value Management, 2016. Stern Value Management - Who are we. [Online] Available at: http://sternvaluemanagement.com/who-we-are-consulting-firm/ [Accessed 1611 2018].

24. STEWART ML (1990). The quest for value. Harper: New York.

25. Stewart, G. B. (1991), The Quest for Value: A Guide for Senior Managers, First Ed., New York: Harper Business.

26. Vasilescu, L. \& Popa, A., 2011. Economic Value Added: Pros and Cons. Finance Challenges of the Future, 1(13), pp. 60-65.

27. Vasilescu, L., (2011), Assessing the firm performance through the financial ratios, Analele Universităţii “Constantin Brâncuşi” din Târgu Jiu, Seria Economie, Nr. 3/2011, pp. 159-166.

28. Worthington, A. C., \& West, T. (2004). Australian Evidence Concerning the Information Content of Economic Value-Added. Australian Journal of Management, 29(2). Retrieved from http://ssrn.com/abstract=2169811

29. Worthington, Andrew and West, Tracey (2001) Economic Value-Added: A Review of the Theoretical and Empirical Literature. Asian Review of Accounting 9(1):pp. 67-86. 